\title{
Temporary skilled international migration of young professional cricketers: 'going Down-Under' to move-up the career path
}

\author{
Catherine A. Waite ${ }^{a^{*}}$, Darren P. Smith ${ }^{b}$ \\ ${ }^{a}$ Environmental and Geographical Sciences, The University of Northampton, Avenue \\ Campus, St George's Avenue, Northampton NN2 6JD \\ ${ }^{\mathrm{b}}$ Department of Geography, Loughborough University, Loughborough, \\ Leicestershire LE11 3TU \\ "Corresponding author: Catherine.waite@northampton.ac.uk
}

Waite, C.A. and Smith, D.P. (2017) Temporary skilled international migration of young professional cricketers: 'going Down-Under' to move-up the career path. Geoforum. 84. 70-76.

\begin{abstract}
Recent theories of temporary skilled international migration tend to be predicated on intra-company overseas transfers and secondments. In this paper we present original findings from a study of cricket migrants to highlight another important form of temporary international movements that enable upskilling from strategic, channelled placements into a foreign club, to propel the careers of young professionals on return migration to their respective home club. Drawing upon interviews with 35 early-career English cricketers, we reveal that moving to Australia for 3-6 months during the English domestic off-season is an increasingly common practice to extend the number of months playing the sport in both distinctive work and climatic conditions. Encountering different overseas sporting cultures and environments is becoming a normative part of formative training and development of young professional cricketers to make the "unfamiliar' more 'familiar" and enhance skills and competencies. We argue that these flows of international migrants have been facilitated by the post-2001 professionalization of cricket, and the institutionalisation of global networks between cricket organisations and key actors in the sport. We suggest that there are parallels between cricket placements and other sports and occupational sectors, such as temporary overseas moves linked to loans (e.g. football), visiting fellowships, internships and secondments, in ever-competitive global professional labour markets.
\end{abstract}

\section{Keywords}


International migration, temporary, cricket, England to Australia, career, professionalization, globalization

\section{Introduction}

In a landmark study, which forged a new agenda for skilled international migration scholarship, Findlay and Gould (1989) emphasised the growing importance of international staff transfers within transnational corporations (TNCs), and the positive impacts on the career advancement of employees. In the three decades since the publication, the influence of globalizing processes on migration, such as the stretching of business networks and the rise of travel mobilities (Castles et al. 2014), have transformed how international migration can act as a key mechanism for the career progression of some professional workers (Beaverstock 2005).

The extended internationalization of business practices and the continuing growth of TNCs (Beaverstock et al. 2015) mean that within many sectors of business, employees are normatively required to have knowledge and experience of a company's international operations (Findlay 2002; Salt and Wood 2012), and of different working conditions and contexts (Harvey and Beaverstock 2016; Faulconbridge and Hall 2012). As a result, many international businesses now directly incorporate overseas secondments in their employee training, development and upskilling programmes.

Movements overseas for such work experiences are typified by transient stays in the place of destination, and are a growing form of temporary skilled international migration. It is contended that flows of so-called 'mobile workers', for instance, are indicative of temporary forms of international migration (Khoo et al. 2007; Ralph 2015; Williams and Baláž 2005). Yet, understandings of how these wider migration processes influence personal skills development and transfer, and unfold during the temporary relocation of individuals require more attention (Hugo 2016). As Raghuram (2008:9) crucially argues, there is a lack of: "recognition of how the skills of skilled migrants are actually produced and circulated through migratory flows".

The main aim of this paper is to explore ties between temporary overseas relocation and upskilling, using the novel case study of young professional cricketers moving from England to Australia during the off-season of domestic English cricket (October-March). The findings are drawn from a wider investigation of cricket migration from England to Australia that examined how migrants are identified, selected and recruited for migration, from the different perspectives of migrants, facilitators of migration, and the regulating organisations of migration.

The paper is divided into six main sections. The following section provides a brief review of scholarship on temporary skilled international migration, to outline the rationale for a focus on young, early-career cricket migrants and temporary 
international migration. Section 3 discusses the linkages between the professionalization of cricket as a sport and the growth of global connections between cricket clubs and key actors in the sport. This is followed by a description of the methods. Sections 4 and 5 present findings from semi-structured interviews with cricket migrants moving from England to Australia, highlighting two key prominent themes of: enhancing skills in unfamiliar contexts, and moving overseas for career progression. The final section makes some concluding remarks.

\section{Temporary skilled international migration for career progression}

According to Hugo (2004a), the growing global connections between temporary international movements, skills acquisition and development, and transfers within and between organisations need to be better understood. Current understandings reveal that to 'participate' in such temporary relocations for work, the prospective migrant must be firstly identified as a 'skilled worker' by the institutional actor(s) facilitating and regulating the moves (Ho 2011; Harvey 2012). This is to be expected, since those individuals who are likely to be either sent overseas by their organisation, or be recruited by a foreign organisations, are already likely to be in possession of specific skills that are of value to operations, and can be further developed through migration overseas. This is reaffirmed by recent scholarship on temporary international migration per se, which overwhelmingly focuses on highlyskilled professionals; usually defined as those in possession of a tertiary education or relevant qualification, and have at least work experience of three years or more (Harvey 2011b).

Recent empirical studies of these skilled professionals moving overseas for relatively short periods of time (i.e. secondments) also expose positive "win-win-win" outcomes (Castles and Ozkul 2014:27) for the individual migrant, and organisations in places of origin and destination. This can include the mutual sharing/learning of good practices to enhance working cultures and performances in both places of origin and destination. In the context of global banking secondments, for example, Beaverstock (2007) shows how globally-distributing personnel assists in the wider training and development of local staff, contributes to local projects whilst overseas, and, upon return, the career development of migrants is advanced via knowledge gained from overseas business practices. Overseas secondments can enable wider skills transfer, and extend the training and competencies of local workers through direct contact and interactions with the international migrant (Khoo et al. 2003, 2007). Importantly, Hugo (2004b) therefore emphasises the high economic potential of facilitating temporary and return migration to encourage circulatory migration. In a research note written for the Australian parliament, Hugo (2004a:2) exemplifies this connection:

"We must realize that there is much to gain from young Australians leaving Australia and acquiring experience, knowledge and connections in 
foreign nations. However, if a substantial proportion can return, the country can gain a double dividend - not just retaining those talents but having those talents enhanced by a period away".

Hugo's identification of youthful, temporary migration flows influencing longer-term career trajectories serve to demonstrate that the acquisition of skills and knowledge are not spatially-bounded (Williams and Baláž 2008). Indeed, other studies (e.g. Pásztor 2015; Baas 2016) reveal that it can be necessary for an individual to migrate to a different, unfamiliar (international) socio-spatial context, to facilitate the acquisition of specific, new, and different skills and experiences for their career development. This scripted sequencing of (overseas) work experiences can be readily woven into Salt's (1988:388) definition of 'the career', as: "a sequence of jobs held by an individual and related to each other by the acquisition of skill and experience", and begs the need to more fully consider how both skills and careers are uplifted via broader forms of temporary international skilled migration such as placements and internships.

It is important to recognise here that temporary international migration can encompass a wide range of temporalities from short-term business trips overseas, often over days or weeks (Salt 2008), to longer stays for a number of months or years in duration. Nevertheless, this diverse range of temporary international migration is united by migrants not expecting the movement (overseas) to result in a permanent change of residence (Bell and Ward 2000). Notably, previous studies in this field of study have tended to focus on the upper-end temporalities of this spectrum, particularly international secondments of one-to-three years (e.g. Beaverstock and Boardwell 2000). Key here are the pioneering studies of Beaverstock (1994, 1996, 2004, 2005, 2012) which show, for instance, how highlyskilled workers are able to express and apply their skills during temporary international migration, such as via work on intra-company transfers (ICTs), and how the migration of skilled personnel allows knowledge and expertise to be transferred between globally-distributed offices (see Millar and Salt 2008). A distinct scholarship has formed that illuminates the motives, work experiences, and career trajectories tied to overseas intra-company transfers within business, accounting, legal and finance organisations.

Aligned to this direction of travel is flourishing research on temporary international movements within academic, science, research and development, and technology organisations (e.g. Mahroum 2000, Harvey 2008, 2011a, OECD 2008), which closely map onto the oft-cited typologies of international skilled migrants within geographic scholarship (i.e. Salt 1988; King 2012). Surprisingly, one occupational grouping within these typologies that has tended to be overlooked in studies of temporary international migration, to date, are sports professionals. It is noteworthy that the lack of attention from geographers (Bale 2000, Koch 2017) is in contrast to a wellestablished social science scholarship on international migration and the sports 
industry per se (Gaffney 2014; Agergaard and Ryba 2014). This spans the disciplines of economics (e.g. Gratton et al. 2011), history (e.g. Coleman 2011), sociology (e.g. Maguire 2011), and anthropology (e.g. Appadurai 1996). Moreover, the absence of geographers within these debates has long been recognised by leading sports scientists (Elliott and Maguire 2008), particularly within studies of migration and cricket (Maguire and Stead 1996, 2005; Stead and Maguire 1998); which is central to this paper. To contribute to these debates, the following sections provide a geographic perspective of temporary international migration of young professional cricketers from England to Australia.

\section{The professionalization of cricket and international migration}

During the last two decades there has been a rising flow of English county professional cricketers leaving the UK during the domestic off-season to play cricket overseas. The post-war origins of this international migration pathway is linked to the historical six-month contracts of cricketers (employed from $1^{\text {st }}$ April to $30^{\text {th }}$ September), despite the long-standing professional set-up of English County Cricket and the availability of financial rewards for the incoming overseas players (Lee 1997). Consequently, English cricketers began to undertake international migration and take up opportunities to play overseas from the early-1970s. Ease of travel and time restrictions meant that early migrations were often to South Africa. However, the rise of the 'Jet Age' (Down 1985), and the political tensions arising from Apartheid in South Africa (Gemmell 2004), led to Australia becoming an increasingly feasible and popular migration destination for English professional cricketers (James 2013), and seasonal migrations to Australia increased from the mid-1970s. This period also represented a period of commercialization within the sport (Lemmon 1987), and there was a strategic recruitment of high-profile English professionals (such as Geoffrey Boycott) to represent Australian cricket teams, and promote the brand of Australian cricket. Such established international English cricketers were available to partake in this form of temporary international migration given that England international tours did not take place every winter (Steen 2009). Senior England cricketers were recruited to play in Australia on the basis of their reputation, so that the host clubs could market their brand value, in much the same way as overseas professionals were sometimes used in English club cricket leagues (Hill 1994).

As the sport of cricket became increasingly shaped by processes of globalization and professionalization (see Heenan and Dunstan 2015), the enabling conditions for the increased flow of temporary international migration were more fully crystallised. It has already been noted that six months contracts in English professional cricket meant that international migration was an attractive opportunity, allowing cricketers to more fully work within their primary career all year round (see Stewart 2012). With more professional cricketers seeking to relocate overseas for the winter months, the 
network of cricketers and agents with contacts in Australia was exploited (Johnston 2016), thus, increasing the opportunities for relocation from the 1980s (Pennell 2012).

This practice in the sport was dramatically transformed in the late 1990s following the introduction of twelve-month contracts in English professional cricket (King 2011), and the deepening professionalization of the sport. The result is that, at both the county and national level, every individual became involved in playing and training throughout the summer season and having a tailor-made fitness and training programme for the off-season, and for some players, this may include a period of time playing and training overseas for upskilling. This is especially important for cricketers and the sport, as the physical (and mental) challenges of cricket are geographically-specific, tied to different climatic conditions and contexts such as the effects of wet/dry pitches/wickets and atmospheric conditions for ball movement and speed. This is one of the key reasons why there has been an exponential increase in the number of individuals migrating to Australia during the off-season months, which provides very different climatic and cultural conditions to England. Australia has thus become the destination of choice for many cricketers and clubs seeking to place employees in different environments overseas, in conjunction with the networks and relationships that developed in the earlier stages of this migration and the welldeveloped and competitive nature of the cricket that is available in Australia, when compared to countries such as South Africa (Kampmark 2013). It is this perception of the need for early-career professional cricketers to experience previously unfamiliar overseas conditions, and the potential for individuals to be involved in cricket all year round that has led to Australian cricket being seen as a "Finishing School" for English professionals (Stead and Maguire 1998). This phenomena of upskilling migration is in line with talent / career development of some other elite sports such as rugby league (Evans and Stead 2014), and, in contrast, to elite sports such as athletics (Ryba et al. 2015).

For the majority of cricket players who temporarily relocate to Australia, the main motive is to enable upskilling through playing competitive sport in Australian Grade Cricket leagues, and providing experiences and knowledge of new environments and conditions (Cricket Australia 2017). Some cricket migrants are thus strategically 'placed' by their club in a particular Australian Grade Cricket team, which involves weekend matches and training on weekday evenings whilst they are overseas. Other migrants may also co-attend the Darren Lehmann Cricket Academy (DLCA) in Adelaide, established in 2005, with programmes in place for early-career cricketers to develop skills in Australian conditions, and thus reinforce their 'finishing'. The intensive programmes have players training throughout the week and playing for local Grade Cricket teams at weekends (Turner 2013). English cricketers can travel independently to the DLCA, sometimes with support from their counties or philanthropists (Wagg 2011), or alternatively, the DLCA is the current destination of ECB (England and Wales Cricket Board) scholarship recipients. This scholarship is awarded to emerging county cricketers from across the UK to complete a six-month 
programme of fitness, training and playing at the DLCA during the English winter (ECB 2013).

\subsection{Methods}

The following sections present findings from 35 semi-structured interviews with English professional cricketers who have migrated to Australia in the off-season of English county cricket. Interviewees were recruited using a snowball sampling technique, following two initial interviews with leading gatekeepers in the process of cricket migration identified via discussions with the England and Wales Cricket Board's National Performance Centre at Loughborough University. At the time of the interviews, all participants held contracts with a range of English professional cricket clubs. When interviewed, migrants were at a range of career stages, but all of their temporary international moves to Australia had taken place in the early stages of their careers. Given it was necessary to ensure anonymity of the interviewees pseudonyms were used to maintain confidentiality given the high media profile of the players in English cricket (Burdsey 2010). The specific ages and playing positions of interviewees are embedded with the quotes in the following section, to provide some important contextual information about the interviewees.

One-hour, individual, face-to-face or telephone, semi-structured interviews with cricketers were undertaken. Face-to-face interviews were conducted at professional cricket grounds, or at the England and Wales Cricket Board's National Performance Centre at Loughborough University. As a starting point, interviewees were informed the study aimed to investigate their experiences of migrating to Australia in the English off-season, and the personal and professional impacts of these temporary migrations. The interviews included open-ended questions to expose, for example career biographies, motives and benefits for going to Australia. This allowed interviewees to answer questions in their own words, and convey their personal views on the subjects. Follow-up questions were used to add depth of understanding. All of the interviews were digitally recorded and transcribed in full as soon as possible after conducting the interview. All qualitative data was inputted into NVivo10 and the data were organised by some initial codes that were constructed from a literature review (Charmaz 2006). As the process of coding and data analysis advanced, it was possible to distinguish between the specificities of different individual migratory experiences and outcomes, as presented in the following sections.

\section{Enhancing skills through work experience(s) in unfamiliar contexts and work cultures}


In much the same way that contemporary overseas secondments are used by international businesses to allow employees to gain experience of foreign business cultures and conditions (e.g. Salt and Wood 2012; Beaverstock and Hall 2012), young cricket migrants moving since 2001 emphasised the significance of overseas experience for enhancing their skills development. Shaun, a 20 year old batsman, summarised his main reasons for relocating to Australia, and also indicated that he perceived his experience to be reflective of other peers:

"A massive thing [for moving] was obviously the cricket and to experience a different cricket culture. But that's what everyone goes to Australia for I think, just to experience a different culture and play hard fought cricket".

Likewise Oliver, a batsman in his early twenties, and who had just returned from Adelaide to enhance his batting skills, reinforced this point, noting:

"I think it helps you because you get different conditions thrown in front of you and wickets that you're not used to".

Tom, a young spin bowler, stated that it was opportunities for the enhancement of bowling skills that encouraged him to migrate to Australia immediately after leaving school:

"My key reasons for going away, it would be to gain more experience, in my cricket, that would be my main one. And learn bowling in Australia [sic], because obviously it is quite a lot different to playing in England".

Tom also pointed to Australia as representing the most highly prized location for young professional cricketers to sharpen their skills overseas:

"At the time they [Australia] were probably seen as the best country cricket-wise, because they'd dominated world cricket for a while. So everybody wanted to go out there, because it is different, I suppose, and give it a go. Different pitches, different weather and all that kind of thing".

The desire to migrate to the most esteemed location is a widely recognised motive for professional migrants (Beaverstock 2002; Harvey 2011a; Ryan and Mulholland 2014), and skilled athletes (Darby and Solberg 2010; Agergaard 2008) per se. Presence in industry-specific prestigious locations enables migrants to have access to new colleagues and professional cultures (Schinke et al. 2013; Weedon 2012), allowing knowledge(s) to be shared and transferred between migrant and host workers (Williams 2007a). This too was seen to be a benefit of temporary migration early in a professional cricket career. Aaron described: 
"You get away from people who have seen you play all your life and then you go and see someone else and they'll tell you something different, and then you think about why they are saying that, you know what I mean? It helps you skills-wise just to get a different opinion".

However, participating in temporary migration not only facilitated skill acquisition and development, it also provided opportunities for the early-career cricketers to have new experiences that could subsequently enable career progression upon return to England. For instance, Alfie, who was 23 years old when he migrated, recalled how he intended his migration to provide him with opportunities for gaining experience that he could not obtain in England:

"The main one was to try and get experience because there was a period towards the back end of last season in England where the older wicketkeeper retired and then we signed another guy on loan, who we then signed full time and I asked why I didn't even get given a chance. They said it was a lack of experience; they wanted to get promoted so they wanted an experienced guy in there. And I was like, how do I get experience without playing? So the main reason was to go out and play and get a bit of experience".

Of course, new experiences that are encountered overseas are not always directly transferable back to the UK context (Williams 2007b). Despite this, migrants noted that they were still able to draw on skills developed overseas and apply them in the home environment. For instance, Shane, a wicket-keeper revealed:

"So when you're playing a game here, when you think on this pitch... it might be a quick, bouncy pitch, and I remember working on this in Australia and this is similar to that. So, I guess it's a way of drawing on experience, so it's always going to be positive because you've already had that learning".

Shane's experience provides an example of how "acquired skills and knowledge from overseas may be transferred and used productively" (Ruhs 2006:26) on return.

As well as the professional aspects of career development, migration was believed to be an ideal situation in which to acquire personal skills such as maturity and independence. Migrants were motivated by the potential to develop attributes including responsibility and the ability to succeed in pressured situations which are likely to be encountered in their future careers. Scott reflected, for his first migration, "it was about that sort of experience of being away and being under pressure". Likewise, Noah, who is now 30 years old, recalled that when deciding to migrate for the first time he thought: 
"the experience of playing on different wickets, in different scenarios and having the responsibility of being an overseas player would help my cricket and develop me further".

Undertaking temporary migration early in a career also offers young cricketers the opportunity to experience independence from home and their home employers (Thorn 2009). From the above quotations, it can be seen that opportunities for both personal and professional development were important for many migrants, particularly when they are still early in their careers. Personally, the ability to deal with additional responsibility and the associated pressure was important for migrants, and professionally, migrants highlighted the importance of experiencing new work cultures and enhancing skills that could be applied upon return to English cricket leagues to aid their career progression.

\section{Moving overseas as a stepping-stone for career progression on return migration}

The cricket migrants commonly revealed how they hoped their sojourn to experience overseas environments would impact positively on their careers in the future. First, Aaron described how he believed that familiarity with the Australian cricket conditions would be beneficial in the future, if he were able to progress to playing internationally for England:

"I think playing internationally you're going to play in different countries, so if you've already been out there and experienced the climates and wickets and how they play out there, then it's obviously going to have a beneficial effect on you isn't it?"

This view, on the opportunity to experience previously unfamiliar conditions, supports findings from previous research on temporary migration, that identified the importance of gaining situated knowledge and skills (Williams and Baláž 2005), and international experience which become valuable assets upon returning home (Williams 2007a). Furthermore, the importance of overseas experiences for developing and progressing (Engh and Agergaard 2015; Li et al. 1996) as an English professional cricketer reflects what Erel (2010:649) terms the "exchange value" of skills. In this case, the ability to perform successfully in Australia may not necessarily be valuable whilst in Australia, because of the number of individuals with similar skillsets (e.g. batting, bowling and fielding in different 'foreign' climate and conditions); however, upon return, the reduced frequency of individuals with such skills means that the skill-set becomes more valuable. It was for these reasons that Tom referred to his time in Australia playing club cricket as a 'stepping-stone' in his career: 
"I think it's a good stepping-stone. I think everyone should really, if they are thinking of doing a sport, cricket, then l'd always suggest for them to go away and experience different places. I know I went back there three times [to play club cricket], and l'd always suggest that if you get an opportunity to go and to go somewhere else, then take it".

The notion of temporarily 'stepping-down' from professional English county cricket to Australian club cricket to enable a positive stepping-stone for career progression directly reflects Williams' view (2007b:374): "In the context of cycles of migration, the stepping stones may not be to jobs in the destination, but via return migration to jobs in their country of origin". Whilst this may appear to devalue skills (Al-Ariss and Crowley-Henry 2013; Bauder 2015), it is intended that it will enable accelerated development, and thus, career progression following the return home.

This was the case for Shaun who expressed: "I think because I went away, that was at the start of my career, so I think it just helped me kick-start my professional life, as far as training well and eating well, all that sort of stuff". The importance of participating in migration early in a career, like Shaun, is demonstrated by Niopek et al. (2011) who encourage migration to take place early, prior to an individual becoming settled and set in their ways as a professional.

Like Shaun and Tom, Jamil spoke of his migration as representing a transition period in his career:

"At the time I didn't actually know how good it was going to be and how it would affect me. But looking back on it, it was the best period of my cricketing career, the transition, the switch, what it did to me in such a short space of time was unbelievable".

As with Shaun the "switch" that Jamil refers to occurred early on in his career as a professional cricketer and enabled him to progress his career upon his return to England. This was true for Edward, who described how he felt that his migration had had similar consequences:

"There were a lot of guys my age, so I was 18 , who I was on a par with, but the experience of going away, growing up and making decisions for myself, I think it accelerated my progress and I think when I came back I was ahead of those guys... I knew I was a good school boy cricketer but it made me think I could do this game properly because l've travelled all the way around the world and l've still done well against men in a competitive environment. I'd go as far as saying I don't think l'd have been a professional cricketer had I not taken that leap". 
Such impacts of international migration have been identified within the wider scholarship in the field. For example, Hamza (2010:53) considers migratory events such as these to be a "catalyst" for the development of the individual migrants. The impact of migration and how it was later considered to be a pivotal moment in the careers of individuals reflects the findings of Williams (2007b: 372 ), who refers to such migrations as "transformational experiences", and "significant-learning moments" (p.377). Whilst Tom, Shaun, Jamil and Edward all refer to the significance they felt that their migration had on their careers, in terms of developing their skills, Edward was more explicit in revealing the skills and confidence that he acquired during his migration as an 18 year old and attributes his subsequent success in his career as a professional cricketer to having undertaken a temporary migration. Yet, nonetheless, all of these migrants considered their migrations to be a stepping-stone in their career and a pivotal moment in their career trajectory.

The significance of the potential impact on career progression is further highlighted through the example of Stuart's career trajectory. Stuart first undertook seasonal migration having lost his professional contract the previous year, and viewed migration as a route back into a career in county cricket:

"I was highly motivated to go because, you know, l'd decided that I wanted to get back into the professional game so I had to do some work and make sure that the following season I hit the ground running... I was pretty much willing to put my life on hold to make sure that my cricket, you know, I got to where I wanted with my cricket... I just thought, right, well, I'll just go for it; I didn't want to die wondering. That was the thing, if I wasn't going to make it as a professional".

Stuart is now able to reflect upon the pivotal nature of his migration on his career, and has since continued to migrate annually to enable him to continue to progress his career.

The above examples demonstrate how temporary international migration can influence career trajectories in English professional cricket following return migration. Our findings concur with Richardson and Mallon's (2005:415) view that experiences gained from international migration can give individuals "the edge in career progression". Key here are the benefits of demonstrating the ability to survive and perform in foreign environments (Cohen et al. 2015). Overall, our empirical findings show how and why temporary international migration is becoming more normalized as part of the formative career progression within professional cricket.

\section{Discussion and conclusion}

In this paper we have sought to widen understandings of the inter-connections between motives, work experiences, career trajectories and temporary skilled 
international migration, by placing a focus on upskilling via channelled placements in different overseas organisations. Findings from our novel case study serve to demonstrate how off-season sojourns to Australia are increasingly becoming a normative early-career pathway for some young professional English cricketers. This shift is facilitated by the professionalization of cricket as a global sports industry, and the rolling out of 12 month employment contracts for professional cricketers. In a similar vein to recent studies of other professional occupations such as academia (Bauder 2015), science and research (Jonkers and Cruz-Castro 2013), and information and communication technology (Roos 2013), our findings point to the growing practice of more and more professional workers enhancing their skills and career trajectories via first-hand experience and knowledge of foreign and unfamiliar contexts (Hugo 2004a). At the same time, there may be important parallels here to other sports, such as international fixed-term loans of football players, and overseas temporary moves associated with some visiting fellowships (e.g. academia, charities), and internships and secondments (e.g. health care). What this suggests is that there is much potential to build upon the pioneering work of authors such as Beaverstock in this field, and widen the lens of analysis to other occupational sectors.

Although such highly-skilled migrants have previously been considered 'invisible migrants' (Koser and Salt 1997; Findlay and Cranston 2015), our findings suggest that moving internationally at formative and early stages of a career is enriching, yet may have many unintentional consequences. It is plausible, for instance, that the rise of these temporary forms of skilled international migration will mean that these migrant groups and processes are more fully 'visible' in future research, policy and society. It will be important to consider the wider potential social and economic costs and implications, and this poses some interesting questions for follow-up research. From an individual perspective, how does temporary international migration impact upon dynamic relationships with partners, families and friendship networks? Does tied or family migration (Clerge et al. 2015) take place during these forms of temporary international migration, and / or is there increasing reliance on digital technologies such as social media and Skype in order to maintain family and friend relationships through the duration of migration (Thulin and Vilhelmson 2014)? Likewise, as careers become increasingly transnational in nature, does the increased spatial mobility of some individuals have implications for the migrant's sense of belonging and feelings of attachment to host locations? Whilst the implications of this, and the extent to which migrants become embedded in their temporary destinations is already evident in migration scholarship (eg. Beaverstock 2005, 2011; Ho 2011; Bahn 2015), it is important to further consider its significance given the normalization of temporary migration as part of professional worker's career trajectories.

We have also shown in this paper that the cricket migrants consider personal development to be an important consequence of their migration in terms of the 
career progression. Despite these career impacts, personal development is ordinarily seen to be separate to professional development. Instead, themes such as pathways to independence and responsibility, highlighted in broader research on gap years for example (Ansell 2008, Inkson and Myers 2003, Lyons et al.2012), is notable here. Further research to enhance understandings of the similarities and differences between the practice of taking gap years, and other forms of temporary international migration would be beneficial.

Beyond the personal and institutional perspectives, there is also a need to consider other impacts of temporary international migration, such as the possible environmental costs of temporary, international migration as a normalized practice in the (early) career progression of skilled workers. In a time when there is increasing grounded-evidence on how climate change will impact upon global migration flows (eg. Held 2016; Baldwin 2016; McLeman et al. 2016), there is perhaps a need to more fully consider how skilled international migration may be contributing to global climate change (Hopkins et al. 2016). Thus, whilst there is increasing institutional 'encouragement' and 'expectation' that early-career professional workers are partaking in temporary international migration, it is necessary to question the extent to which it is environmentally sustainable in the longer term, particularly with the development of new technologies such as Skype.

This backdrop serves to highlight that there is potential for further research to more fully examine the regulatory contexts within temporary international migration experiences. This is particularly pertinent with regards to the visa regimes and working regulations that international migrants are required to negotiate as they travel overseas, which will have a bearing on a wide range of transnational athletes, as they move between different national governing bodies for their sport. Indeed, given that much of the existing research on temporary skilled international migration has been focused on transnational corporations, many of these regulatory structures are often avoided as workers move within the same, secure, employment structures. Despite this there is potential for further research that examines the multi-scalar regulatory structures that enable and constrain temporary skilled international migration.

To conclude, using the case study of young English professional cricketers migrating to Australia during the domestic off-season, this paper has illustrated how temporary international migration has become a more common part of the early-career pathways of professionals. Temporary international migration provides an opportunity to be exposed to new and unfamiliar working conditions. Consequently, they are required to both apply and enhance existing skills whilst also learning from locals in the host community to acquire new place-specific skills. These skills are then transferred when the migrant returns to the home location where they can be applied and adapted, as they have become a valuable asset, since all workers do not possess the acquired skills. However, since it is evident that institutions and industries, such as the professional cricket industry, are requiring international 
migratory experiences to become an increasingly normative part of the career trajectory. It is possible that more and more professional workers will be expected to list overseas work experiences on their curricula vitae/profiles, perhaps to uplift or maintain their position in the labour market and stay fixed on the level playing fields with their peers. 


\section{References}

Agergaard, S. (2008). Elite athletes as migrants in Danish women's handball. International Review for the Sociology of Sport, 43(1), 5-19.

Agergaard, S., \& Ryba, T. V. (2014). Migration and career transitions in professional sports: Transnational athletic careers in a psychological and sociological perspective. Sociology of Sport Journal, 31(2), 228-247.

Al Ariss, A., \& Crowley-Henry, M. (2013). Self-initiated expatriation and migration in the management literature: Present theorizations and future research directions. Career Development International, 18(1), 78-96.

Ansell, N. (2008). Third World gap year projects: youth transitions and the mediation of risk. Environment and Planning D: Society and Space, 26(2), 218-240.

Appadurai, A. (1996). Modernity at Large: Cultural Dimensions of Globalization, (Vol. 1). University of Minnesota Press.

Baas, M. (2016). Becoming Trans/Nationally Mobile: The Conflation of Internal and International Migration in the Trajectories of Indian Student-Migrants in Australia and Beyond. South Asia: Journal of South Asian Studies. 39(1), 14-28.

Bahn, S. (2015). Managing the well-being of temporary skilled migrants. The International Journal of Human Resource Management, 26(16), 2102-2120.

Baldwin, A. (2016). Premediation and white affect: climate change and migration in critical perspective. Transactions of the Institute of British Geographers, 41(1), 7890.

Bale, J. (2000). Human Geography and the study of sport. In. Coakley, J., \& Dunning, E. (Eds.) Handbook of Sports Studies, London: Sage.

Bauder, H. (2015). The international mobility of academics: a labour market perspective. International Migration. 53(1), 83-96.

Beaverstock, J. V. (1994). Re-thinking skilled international labour migration: world cities and banking organisations. Geoforum, 25(3), 323-338.

Beaverstock, J. V. (1996). Subcontracting the accountant! Professional labour markets, migration, and organisational networks in the global accountancy industry. Environment and Planning A, 28(2), 303-326.

Beaverstock, J. V. (2002). Transnational elites in global cities: British expatriates in Singapore's financial district. Geoforum, 33(4), 525-538. 
Beaverstock, J. V. (2004). 'Managing across borders': knowledge management and expatriation in professional service legal firms. Journal of Economic Geography, $4(2), 157-179$.

Beaverstock, J. V. (2005). Transnational elites in the city: British highly-skilled intercompany transferees in New York city's financial district. Journal of Ethnic and Migration Studies, 31(2), 245-268.

Beaverstock, J.V. (2007). World City networks 'from below' international mobility and inter-city relations in the global investment banking industry. In. Taylor, P.J., Derudder, B., Saey, P., \& Witlox, F. (Eds.) Cities in Globalization: Practices, Policies and Theories, London: Routledge.

Beaverstock, J. V. (2011). Servicing British expatriate 'talent' in Singapore: exploring ordinary transnationalism and the role of the 'expatriate' club. Journal of Ethnic and Migration Studies, 37(5), 709-728.

Beaverstock, J.V. (2012). Highly Skilled International Labour Migration and World Cities: Expatriates, Executives and Entrepreneurs. In. Derudder, B., Hoyler, M., Taylor, P.J., \& Witlox, F. (Eds.) International Handbook of Globalization and World Cities, Cheltenham: Edward Elgar Publishing Limited.

Beaverstock, J. V., \& Boardwell, J. T. (2000). Negotiating globalization, transnational corporations and global city financial centres in transient migration studies. Applied Geography, 20(3), 277-304.

Beaverstock, J. V., \& Hall, S. (2012). Competing for talent: global mobility, immigration and the City of London's labour market. Cambridge Journal of Regions, Economy and Society, 5, 271-88.

Beaverstock, J. V., Faulconbridge, J. R., \& Hall, S. J. (2015). The Globalization of Executive Search: Professional Services Strategy and Dynamics in the Contemporary World (Vol. 59). London: Routledge.

Bell, M., \& Ward, G. (2000). Comparing temporary mobility with permanent migration. Tourism Geographies, 2(1), 87-107.

Burdsey, D. (2010). British Muslim experiences in English first-class cricket. International Review for the Sociology of Sport, 45(3), 315-334.

Castles, S., \& Ozkul, D. (2014). Circular Migration: Triple win, or a new label for temporary migration?. In. Battistella, G. (Ed.) Global and Asian Perspectives on International Migration, London: Springer.

Castles, S., de Haas, H., \& Miller, M. J. (2014). The Age of Migration: International Population Movements in the Modern World. ( $5^{\text {th }}$ Ed.), Basingstoke: Palgrave MacMillan Higher Education. 
Charmaz, K. (2006). Constructing grounded theory: A practical guide through qualitative research. London: Sage Publications Ltd.

Clerge, O., Sanchez - Soto, G., Song, J., \& Luke, N. (2015). 'I Would Really Like to Go Where You Go': Rethinking Migration Decision - Making Among Educated Tied Movers. Population, Space and Place. doi: 10.1002/psp.1990

Cohen, L., Duberley, J., \& Ravishankar, M. N. (2015). Examining the Interplay of Career, Migration and National Cultural Identity: The Case of Indian Scientists. International Migration. (53)5, 104-121.

Coleman, M. (2011). Review: The Gaelic Athletic Association 1884 -2009. Journal of Sport History, 38(2), 311-313.

Cricket Australia. (2017). Club Cricket. Available on-line at: http://playcricket.com.au/senior-competition/club-cricket (Last accessed: 21/01/2017).

Darby, P., \& Solberg, E. (2010). Differing trajectories: football development and patterns of player migration in South Africa and Ghana. Soccer \& Society, 11(1-2), 118-130.

Down, M. (1985). Is it Cricket?: Power, Money \& Politics in Cricket Since 1945. London: Queen Anne Press.

ECB. (2013). PEPP and Overseas Scholarship Programme Announced. Available on-line at: http://www.ecb.co.uk/news/articles/pepp-and-overseas-scholarshipprogramme-announced (Last accessed: 11/10/2014).

Elliott, R., \& Maguire, J. (2008). Thinking outside of the box: Exploring a conceptual synthesis for research in the area of athletic labor migration. Sociology of Sport Journal, 25(4), 482-497.

Engh, M. H., \& Agergaard, S. (2015). Producing mobility through locality and visibility: Developing a transnational perspective on sports labour migration. International Review for the Sociology of Sport, 50(8), 974-992

Erel, U. (2010). Migrating cultural capital: Bourdieu in migration studies. Sociology, 44(4), 642-660.

Evans, A. B., \& Stead, D. E. (2014). 'It's a long way to the Super League': The experiences of Australasian professional rugby league migrants in the United Kingdom. International Review for the Sociology of Sport, 49(6), 707-727.

Faulconbridge, J., \& Hall, S. (2012). Business knowledges within and between the world city. In. Derudder, B., Hoyler, M., Taylor, P.J., \& Witlox, F. (Eds.) International 
Handbook of Globalization and World Cities, Cheltenham: Edward Elgar Publishing Limited.

Findlay, A. (2002). From brain exchange to brain gain: policy implications for the UK of recent trends in skilled migration from developing countries. International Migration Papers, No. 43, Geneva: International Labour Office.

Findlay, A., \& Gould, W. T. S. (1989). Skilled international migration: a research agenda. Area, 21(1), 3-11.

Findlay, A.M., \& Cranston, S. (2015). What's in a research agenda? An evaluation of research developments in the arena of skilled international migration. International Development Planning Review, 37(1), 17-31.

Gaffney, C. (2014). Geography of Sport. In. Maguire, J.A. (Ed.) Social Sciences in Sport. Human Kinetics: Leeds

Gemmell, J. (2004). The Politics of South African Cricket. London: Routledge.

Gratton, C., Liu, D.F., Ramchandani, G., \& Wilson, D. (2011). The Global Economics of Sport, London: Taylor \& Francis.

Hamza, A. (2010). International experience an opportunity for professional development in higher education. Journal of Studies in International Education, 14(1), 50-69.

Harvey, W. S. (2008). The social networks of British and Indian expatriate scientists in Boston. Geoforum, 39(5), 1756-1765.

Harvey, W. S. (2011a). British and Indian scientists moving to the United States. Work and Occupations, 38(1), 68-100.

Harvey, W. S. (2011b). Immigration and emigration decisions among highly skilled British expatriates in Vancouver. Global Knowledge Workers: Diversity and Relational, 33-56.

Harvey, W. (2012). Brain circulation to the UK?: Knowledge and investment flows from highly skilled British expatriates in Vancouver. Journal of Management Development, 31(2), 173-186.

Harvey, W.S. and Beaverstock, J.V. (2016). Diverging experiences of work and social networks abroad: Highly-skilled British migrants in Singapore, Vancouver and Boston. In van Riemsdijk, Micheline and Qingfang Wang (Eds.) Rethinking International Skilled Migration: A Place-Based and Spatial Perspective, London: Routledge. 
Heenan, T., \& Dunstan, D. (2015). 'Let them eat cake': Bradman, the Board \& the Packer Revolution. Sport in Society: Cultures, Commerce, Media, Politics, 18(9), 1132-1146.

Held, D. (2016). Climate Change, Migration and the Cosmopolitan Dilemma. Global Policy. doi: 7(2), 237-246.

Hill, J. (1994). Cricket and the Imperial Connection: Overseas Players in Lancashire in the Inter-war Years. In. Maguire, J.A. and Bale, J. (Eds.) The Global Sports Arena: Athletic Talent Migration in an Interdependent World. London: Frank Cass Publishers.

Ho, E. L. E. (2011). Migration trajectories of 'highly skilled' middling transnationals: Singaporean transmigrants in London. Population, Space and Place, 17(1), 116-129.

Hopkins, D., Higham, J., Tapp, S., \& Duncan, T. (2015). Academic mobility in the Anthropocene era: a comparative study of university policy at three New Zealand institutions. Journal of Sustainable Tourism, 1-22.

Hugo, G. (2004a). A new paradigm of international migration: implications for migration policy and planning for Australia. Parliamentary Library: Department of Parliamentary Services Research Note, 46 (8 ${ }^{\text {th }}$ March 2004).

Hugo, G. (2004b). A new paradigm of international migration: implications for migration policy and planning for Australia Parliamentary Library: Department of Parliamentary Services Research Paper, No. 10 (2003-2004).

Hugo, G. J. (2016). Internal and international migration in East and Southeast Asia: exploring the linkages. Population, Space and Place. 22(7), 651-668.

Inkson, K., \& Myers, B. A. (2003). "The big OE": self-directed travel and career development. Career development international, 8(4), 170-181.

James, S. (2013) The Plan: How Fletcher and Flower Transformed English Cricket. London: Bantam Books

Johnston, R. (2016) The toughest finishing school in cricket. Available on-line at: http://www.espncricinfo.com/magazine/content/story/959595.html (Last accessed: 21/04/2017)

Jonkers, K., \& Cruz-Castro, L. (2013). Research upon return: The effect of international mobility on scientific ties, production and impact. Research Policy, 42(8), 1366-1377.

Kampmark, B. (2013). Australian cricket: the diminishing light. Sport in Society: Cultures, Commerce, Media, Politics, 16(1), 45-55. 
Khoo, S. E., Voigt-Graf, C., Hugo, G., \& McDonald, P. (2003). Temporary skilled migration to Australia: the 457 Visa Sub-Class. People and Place, 11(4), 27-40.

Khoo, S. E., Voigt - Graf, C., McDonald, P., \& Hugo, G. (2007). Temporary Skilled Migration to Australia: Employers' Perspectives. International Migration, 45(4), 175201.

King, A. (2011). The reverse sweep. Sport in Society: Cultures, Commerce, Media, Politics, 14(10), 1395-1406.

King, R. (2012). Geography and migration studies: Retrospect and prospect. Population, Space and Place, 18(2), 134-153.

Koch, N. (2017) Introduction: Critical geographies of sport in global perspective. In. Koch, N. (Ed.) Critical geographies of sport: space, power and sport in global perspective. London: Routledge.

Koser, K., \& Salt, J. (1997). The geography of highly skilled international migration. International Journal of Population Geography, 3(4), 285-303.

Lee, A. (1997). Raising the Stakes: The Modern Cricket Revolution, London: Victoria.

Lemmon, D. (1987). Cricket Mercenaries - Overseas Players in English Cricket, London: Pavilion Books Ltd.

Li, F. L. N., Findlay, A. M., Jowett, A. J., \& Skeldon, R. (1996). Migrating to learn and learning to migrate: a study of the experiences and intentions of international student migrants. International Journal of Population Geography, 2(1), 51-67.

Lyons, K., Hanley, J., Wearing, S., \& Neil, J. (2012). Gap year volunteer tourism: Myths of global citizenship?. Annals of tourism research, 39(1), 361-378.

Maguire, J.A. (2011). Thinking Sociologically about Sport, Sport in Society: Cultures, Commerce, Media, Politics, 14(7-8), 864-871.

Maguire, J.A., \& Stead, D. (1996). Far pavilions?: Cricket migrants, foreign sojourns and contested identities. International Review for the Sociology of Sport, 31(1), 1-23.

Maguire, J.A., \& Stead, D. (2005). Cricketers of the empire': Cash crops, mercenaries and symbols of sporting emancipation. In. Maguire, J.A. (Ed.) Power and Global Sport: Zones of Prestige, Emulation and Resistance, London: Routledge.

Mahroum, S. (2000). Highly skilled globetrotters: mapping the international migration of human capital. R\&D Management, 30(1), 23-32. 
McLeman, R., Faist, T., \& Schade, J. (2016). Introduction: Environment, Migration, and Inequality-A Complex Dynamic. In Environmental Migration and Social Inequality (pp. 3-23). London: Springer International Publishing.

Millar, J., \& Salt, J. (2008). Portfolios of mobility: the movement of expertise in transnational corporations in two sectors-aerospace and extractive industries. Global Networks, 8(1), 25-50.

Niopek, D., Berrens, R., Mockenhaupt, S., Lewis, M. D., Mueller, A. K., \& Grimm, D. (2011). To go, or not to go, that is the question-Six personal reflections on how geographic mobility may affect your career and life. BioEssays, 33(10), 728-731.

OECD (2008). The global competition for talent: mobility of the highly skilled, OECD Publications.

Pásztor, A. (2015). Careers on the Move: International Doctoral Students at an Elite British University. Population, Space and Place, 21(8), 832-842.

Pennell, M. (2012). Northeast plans winter work in Queensland. The Cricketer. Available on-line at:

http://www.thecricketer.com/default.aspx?pageid=985\&topicid=15630 (Last accessed: $11 / 10 / 2014)$

Raghuram, P. (2008). Governing the mobility of skills. In. Gabrielle, C. and Pellerin, H. (Eds.) Governing International Labour Migration: Current Issues, Challenges and Dilemmas. Routledge/RIPE Studies in Global Political Economy London: Routledge. Available on-line at http://oro.open.ac.uk/11808/1/Microsoft Word governing the mobility of skills final.pdf (Last accessed 21/04/2017)

Ralph, D. (2015). 'Always on the Move, but Going Nowhere Fast': Motivations for 'Euro-commuting' between the Republic of Ireland and Other EU States. Journal of Ethnic and Migration Studies, 41(2), 176-195.

Richardson, J., \& Mallon, M. (2005). Career interrupted? The case of the selfdirected expatriate. Journal of World Business, 40(4), 409-420.

Roos, H. (2013). In the rhythm of the global market: Female expatriates and mobile careers: A case study of Indian ICT professionals on the move. Gender, Work \& Organization, 20(2), 147-157.

Ruhs, M. (2006). The potential of temporary migration programmes in future international migration policy. International Labour Review, 145(1 - 2), 7-36.

Ryan, L., \& Mulholland, J. (2014). French connections: the networking strategies of French highly skilled migrants in London. Global Networks, 14(2), 148-166. 
Ryba, T.V., Ronkainen, N.J. and Selänne, H. (2015). Elite athletic career as a context for life design. Journal of Vocational Behaviour, 88, 47-55.

Salt, J. (1988). Highly-skilled international migrants, careers and internal labour markets. Geoforum, 19(4), 387-399.

Salt, J. (2008). Global corporate labour markets and the international mobility of expertise Managing Highly Skilled Labour Migration Seminar, Amsterdam. OECD: Paris.

Salt, J., \& Wood, P. (2012). Recession and international corporate mobility. Global Networks, 12(4), 425-445.

Schinke, R. J., McGannon, K. R., Battochio, R. C., \& Wells, G. D. (2013). Acculturation in elite sport: a thematic analysis of immigrant athletes and coaches. Journal of sports sciences, 31(15), 1676-1686.

Stead, D. \& Maguire, J. (1998). Cricket's Global 'Finishing School': The Migration of Overseas Cricketers into English County Cricket. European physical education review, 4(1), 54-69.

Steen, R. (2009). Burning down the house. Sport in Society: Cultures, Commerce, Media, Politics, 12(4-5), 670-680.

Stewart, A. (2012). Alec Stewart Column: How cricket got serious about fitness Available on-line at: http://www.bbc.co.uk/sport/0/cricket/17373797 (Last Accessed 21/04/2017).

Thorn, K. (2009). The relative importance of motives for international self-initiated mobility. Career Development International, 14(5), 441-464.

Thulin, E., \& Vilhelmson, B. (2014). Virtual practices and migration plans: A qualitative study of urban young adults. Population, Space and Place, 20, 389-401.

Turner, M. (2013). Former English pace ace Darren Gough to mentor Adelaide's young grade cricketers. The Daily Telegraph. Available on-line at: http://www.dailytelegraph.com.au/former-english-pace-ace-darren-gough-to-mentoradelaides-young-grade-cricketers/story-e6freuy91226555722235?nk=3156c32dbfb022cfc62eb1af807a81f6 (Last Accessed 21/04/2017).

Wagg, S. (2011). 'The four-day game doesn't pay the bills': Leicestershire, 2010-11: A case study in the contemporary political economy of county cricket. Sport in Society: Cultures, Commerce, Media, Politics, 14(10), 1407-1420. 
Weedon, G. (2012). 'Glocal boys': Exploring experiences of acculturation amongst migrant youth footballers in Premier League academies. International Review for the Sociology of Sport, 47(2), 200-216.

Williams, A. M. (2007a). International labour migration and tacit knowledge transactions: a multi - level perspective. Global Networks, 7(1), 29-50.

Williams, A. M. (2007b). Listen to me, learn with me: international migration and knowledge transfer. British Journal of Industrial Relations, 45(2), 361-382.

Williams, A. M., \& Baláž, V. (2005). What Human Capital, Which Migrants? Returned Skilled Migration to Slovakia From the UK. International Migration Review, 39(2), 439-468.

Williams, A.M. and, Baláž, V. (2008). International Migration and Knowledge, London: Routledge. 